\title{
Treatment of produced water in a floating carrier bioreactor
}

\author{
Ezerie Henry Ezechi ${ }^{{ }^{\dagger}}$, Nasiman Sapari ${ }^{1}$, Ezerie Jane Menyechi ${ }^{2}$, Clement M. Ude ${ }^{3}$, Emmanuel Olisa ${ }^{1}$ \\ ${ }^{1}$ Department of Civil and Environmental Engineering, Universiti Teknologi PETRONAS, 32610 Bandar Seri Iskandar, Perak, Malaysia \\ ${ }^{2}$ Department of Applied Microbiology, Enugu State University of Science and Technology, P.M.B 01660, Enugu, Nigeria \\ ${ }^{3}$ Department of Applied Biochemistry, Enugu State University of Science and Technology, P.M.B 01660, Enugu, Nigeria
}

\begin{abstract}
Produced water is the largest wastestream of oil and gas exploration. It consists of various organic and inorganic compounds that hinder its beneficial use. This study compared the treatment of produced water in a batch suspended and biofilm activated sludge process. The biofilm carrier material was made from Gardenia Carinata shell. COD, $\mathrm{NH}_{4}{ }^{+}-\mathrm{N}$ and $\mathrm{NO}_{3}-\mathrm{N}$ removal was monitored in both the suspended (control) and floating carrier bioreactors. The results show a rapid reduction of produced water constituents in the floating carrier bioreactor. COD, $\mathrm{NH}_{4}{ }^{+}-\mathrm{N}$ and $\mathrm{NO}_{3}-\mathrm{N}$ removal was in the range of $99 \%, 98 \%$ and $97 \%$ for the floating carrier bioreactor whereas it was $88 \%, 84 \%$ and $83 \%$ for the control bioreactor. The rapid reduction of $\mathrm{COD}, \mathrm{NH}_{4}{ }^{+}-\mathrm{N}$ and $\mathrm{NO}_{3}-\mathrm{N}$ clearly indicate that the floating carrier materials served as an attached growth medium for microorganisms, improved the breakdown of produced water constituents and reduced inhibition of microbial metabolic activities.
\end{abstract}

Keywords: Bioreactor, Floating carrier material, Gardenia carinata, Produced water

\section{Introduction}

The increasing population growth and urbanization has caused an increase in water usage and a decline in the available renewable water resources [1, 2]. Additionally, water requirement in the agricultural sector is increasingly high due to the demand in food production. In this circumstance, the dependency of the agricultural sector on the limited available renewable water resources for irrigation could be counterproductive. A good water management strategy and adjustment are required to avert the impending water scarcity [3]. Thus, reclamation of wastewater could serve as a supplement to the limited renewable water resources [1, 4].

One of the available, abundant and neglected secondary water resource is produced water [5]. Produced water is a by-product of oil well operation which is trapped in underground formation and brought to the surface along with oil and gas during drilling. It is separated from crude oil above ground in an oil/water separator.

As the demand for crude oil increases, the generation of produced water increase proportionately. Produced water is reportedly the largest waste-stream of oil and gas exploration with an estimated 250 million barrels per day compared with about 80 million barrels per day of oil production [6]. Its composition is complex and depends on geological conditions, storage formation and type of recovery method [7]. Produced water generation is usually low in the early stages of oil and gas operation but can rise to as high as $\mathbf{8 0} \%$ during the later years [8]. Produced water can be toxic to the environment due to its high organic and inorganic constitutents [9]. Produced water may comprise of flow from above or below the hydrocarbon zone, flow from fluids injected during operation and flow from within the hydrocarbon zone. The hydrocarbon content of produced water includes organic acids, polycyclic aromatic hydrocarbons (PAHs), phenols and volatiles [10]. These compounds are toxic to aquatic organisms when they combine together [11]. The chemicals used during oil and gas production are complex mixtures of various molecular compounds which can also increase the potential toxicity of produced water [12]. Thus, it is important to adequately treat produced before possible discharge or reuse.

Several methods have been investigated for produced water treatment. However, some of these methods are associated with demerits. Coagulation and flocculation can effectively remove suspended and colloidal particles but are less effective for dissolved constituents [6]. Electrodialysis is unsuitable for the treatment of produced water with high total dissolved solid (TDS) concentration [13]. Electrocoagulation is a simple and easy technique
This is an Open Access article distributed under the terms of the Creative Commons Attribution Non-Commercial License (http://creativecommons.org/licenses/by-nc/3.0/) which permits unrestricted non-commercial use, distribution, and reproduction in any medium, provided the original work is properly cited.
Received October 4, 2016 Accepted January 16, 2017

${ }^{\dagger}$ Corresponding author

Email: honhenry2k5@gmail.com

Tel: +60-165455924 Fax: +60-53676552

Copyright (C) 2017 Korean Society of Environmental Engineers 
but could be affected by passivation [14]. Membrane technologies are effective techniques but are associated with membrane fouling which increases its cost [15]. A COD and $\mathrm{NH}_{3}-\mathrm{N}$ removal of 63.5 and $45 \%$ was achieved in a biological treatment of produced water [8]. Thus, there is need for a more effective and sustainable method for produced water treatment.

Several biofilm materials have been used in activated sludge process to improve bacteria population and improve system performance. Liu et al. [16] examined the performance of a combined upflow anaerobic sludge blanket (UASB) and immobilized biological aerated filter (IBAF) in a pilot scale experiments treating heavy oil wastewater using Polycin Urepan as carrier material. Han et al. [17] compared the performance of a pilot scale biological aerated filter (BAF) equipped with lava particles as carrier material and a drinking water treatment plant for ammonia and manganese removal. Sarti et al. [18] examined the performance of a horizontal-flow anaerobic immobilized biomass (HAIB) system treating low strength wastewater using polyurethane foam blocks as carrier material. High wastewater treatment capacity were all achieved with the various carrier materials.

The focus of this study is to investigate the performance of an abundant agricultural solid waste precusor (Gardenia Carinata shell) as a carrier material for the treatment of produced water in a batch activated sludge process. Gardenia Carinata is a small to medium tree, native to sunny environments. It is commonly used for landscaping and produce seeds that later develop into flowers with an internal part that is shelly. These shells contribute to solid waste production. Due to the environmental constraints in the development of new landfills [19], economic utilization of abundant and recyclable agricultural solid waste materials has intensified.

\section{Materials and Methods}

\subsection{Wastewater Collection}

The produced water used in this study was collected from a local oil and gas exploration terminal in Malaysia. The produced water was characterized in accordance with the standard methods for the examination of water and wastewater [20]. The complete wastewater characteristics is reported elsewhere [21, 22]. The COD, $\mathrm{NH}_{4}{ }^{+}-\mathrm{N}, \mathrm{pH}$ and TSS concentrations were in the range $1,480 \mathrm{mg} / \mathrm{L}$, $14 \mathrm{mg} / \mathrm{L}, 7.84 \mathrm{mg} / \mathrm{L}$ and $166 \mathrm{mg} / \mathrm{L}$, respectively.

\subsection{Floating Carrier Material}

Gardenia Carinata Shell was collected within Universiti Teknologi PETRONAS (UTP). Gardenia Carinata Shell was severally washed and dried under the sun-light. The shells were manually broken and separated. The shells were then washed severally and dried at $105^{\circ} \mathrm{C}$. Thereafter, the shells were manually cut into floating carrier materials of size $2 \mathrm{~cm} \times 2 \mathrm{~cm} \times 0.2 \mathrm{~cm}$ (width $\times$ length $\times$ height). The floating materials are low density materials with a relative density of $0.19 \mathrm{~g} / \mathrm{cm}^{3}$ and a specific surface area of $4 \mathrm{~m}^{2}$. Oxygen was supplied to the air diffusers from an inbuilt air pump. The air flow was monitored using a rotameter and validated using a DO meter. The reactor was aerated at an air flow rate of 1.14 L.h in order to retain the floating carrier material in suspension.

\subsection{Bioreactor Set-up}

Two cylindrical shaped identical bioreactor of equal volume (5 L) were made from acrylic glass and set up in the laboratory. A thick polystyrene foam board was fixed at the bottom of the bioreactors to hinder friction and turbulence between the reactors and their stand. The reactors were covered with aluminum foil to simulate a closed system. A horizontal thin lining was made at the bottom for the installation of air diffusers. The first bioreactor was a biofilm system and was supplied with floating carrier materials whereas the second bioreactor was a suspended growth system used as control mechanism to evaluate the performance of the biofilm system.

\subsection{Bioreactor Start-up}

The floating carrier bioreactor (FCB) was started by adding 150 pieces of carrier materials into the bioreactor. Seed sludge $(1 \mathrm{~L})$ with mixed liquor suspended solids (MLSS) of $3,472 \mathrm{mg} / \mathrm{L}$ was collected from a domestic wastewater treatment plant in UTP and was added to FCB. Real produced water was diluted to a COD concentration of about $150 \mathrm{mg} / \mathrm{L}$ and $0.8 \mathrm{~L}$ was fed to FCB to initiate biofilm formation and acclimatization. After acclimatization (2-3 d), 0.25 L of the supernatant was withdrawn from FCB and $3.4 \mathrm{~L}$ of real produced water was added to the reactor. The purpose was to have more raw wastewater within the reactor volume $(5 \mathrm{~L})$. The air flowrate was calibrated to obtain a flow that can maintain the carrier materials in suspension. In the control bioreactor (CB), a similar approached was adopted for start-up, but the carrier materials were excluded.

\subsection{Bioreactor Operation}

Oxygen was provided in both FCB and CB through two ceramic air diffusers installed at the bottom of the bioreactors and connected to an inbuilt-air pump. Supernatants $(30 \mathrm{~mL})$ were withdrawn from both bioreactors (FCB and CB) at intervals of $12 \mathrm{~h}$. The residual COD, $\mathrm{NH}_{4}{ }^{+}-\mathrm{N}$ and $\mathrm{NO}_{3}-\mathrm{N}$ concentration was measured using the Hach methods [23]. pH, DO and temperature were daily monitored concurrently using a $\mathrm{pH}$ meter (Sension ${ }^{\mathrm{TM}}$ ), DO meter (YSI $550 \mathrm{~A}$ ) and a thermometer (Thermolyne P/N MEX - 147 IMM 76 MM MCT). The pH meter, DO meter and thermometer were purchased from Hach USA, Palmer Wahl Instrumentation Group USA and YSI incorporated USA, respectively. All sample analysis were triplicated.

\section{Results and Discussion}

Fig. 1 shows the COD result for FCB and CB after acclimatization. Effluent COD concentration decreased to $873 \mathrm{mg} / \mathrm{L}$ in FCB and $1,097 \mathrm{mg} / \mathrm{L}$ in $\mathrm{CB}$ at the end of day 1 . On day 2, effluent COD concentration decreased to $206 \mathrm{mg} / \mathrm{L}$ in FCB and $416 \mathrm{mg} / \mathrm{L}$ in CB. On day 3, effluent COD concentration further decreased to $21 \mathrm{mg} / \mathrm{L}$ in FCB and $181 \mathrm{mg} / \mathrm{L}$ in CB. No further improvement was observed on day 4 as the bioreactors stabilized. The $\mathrm{BOD}_{5}$ 
concentration at the end of the study was $17 \mathrm{mg} / \mathrm{L}$ for FCB and $79 \mathrm{mg} / \mathrm{L}$ for CB.

The effluent $\mathrm{NH}_{4}{ }^{+}-\mathrm{N}$ concentration at the end of day 1 was $2 \mathrm{mg} / \mathrm{L}$ in FCB and $6.15 \mathrm{mg} / \mathrm{L}$ in $\mathrm{CB}$ as shown in Fig. 2. On day 2, effluent $\mathrm{NH}_{4}{ }^{+}-\mathrm{N}$ concentration in FCB was $1 \mathrm{mg} / \mathrm{L}$ and $3.3 \mathrm{mg} / \mathrm{L}$ in CB. Effluent $\mathrm{NH}_{4}{ }^{+}-\mathrm{N}$ concentration slightly decreased to 0.25 $\mathrm{mg} / \mathrm{L}$ in FCB and $2.05 \mathrm{mg} / \mathrm{L}$ in $\mathrm{CB}$ on day 3. The $\mathrm{NH}_{4}{ }^{+}-\mathrm{N}$ removal coincided with $\mathrm{NO}_{3}-\mathrm{N}$ removal in FCB and $\mathrm{CB}$ as represented in Fig. 3.

Fig. 3 shows that $\mathrm{NO}_{3}-\mathrm{N}$ concentration decreased on day 1 and reached approximately $0.7 \mathrm{mg} / \mathrm{L}$ and $1.9 \mathrm{mg} / \mathrm{L}$ in FCB and $\mathrm{CB}$, respectively. However, the $\mathrm{NO}_{3}-\mathrm{N}$ concentration increased to $1.9 \mathrm{mg} / \mathrm{L}$ and $3.1 \mathrm{mg} / \mathrm{L}$ in FCB and CB on day 2. On day 3, $\mathrm{NO}_{3}-\mathrm{N}$ concentration decreased to $0.13 \mathrm{mg} / \mathrm{L}$ and $0.7 \mathrm{mg} / \mathrm{L}$ in FCB and $\mathrm{CB}$ on day 3.

The COD, $\mathrm{NH}_{4}{ }^{+}-\mathrm{N}$ and $\mathrm{NO}_{3}-\mathrm{N}$ removal is summarized in Table 1. The FCB performance was higher in comparison to CB.

The mechanism of COD removal by both bioreactors could be attributed to carbonaceous substrate consumption [24]. The oxidation of organic matter by microorganisms results in cell synthesis, growth and cell maintainance. $\mathrm{NH}_{4}{ }^{+}-\mathrm{N}$ removal in both bioreactors were governed by the autotrophic oxidation of ammonia, first to nitrite and then, to nitrate [25]. The decrease and increase of $\mathrm{NO}_{3}-\mathrm{N}$ concentration on day 1 and 2 in FCB and $\mathrm{CB}$ was caused by the oxidation of $\mathrm{NH}_{4}{ }^{+}-\mathrm{N}$ to $\mathrm{NO}_{3}-\mathrm{N}$ during nitrification. The low effluent concentration of $\mathrm{NO}_{3}-\mathrm{N}$ on day 3 represented an uptake in microbial growth [26]. The increase of $\mathrm{NO}_{3}-\mathrm{N}$ concentration on day 2 was due to nitrification, which is the two step bio-oxidation of ammonia first to nitrite, and then to nitrate. The results show that $\mathrm{NO}_{3}-\mathrm{N}$ removal was higher in

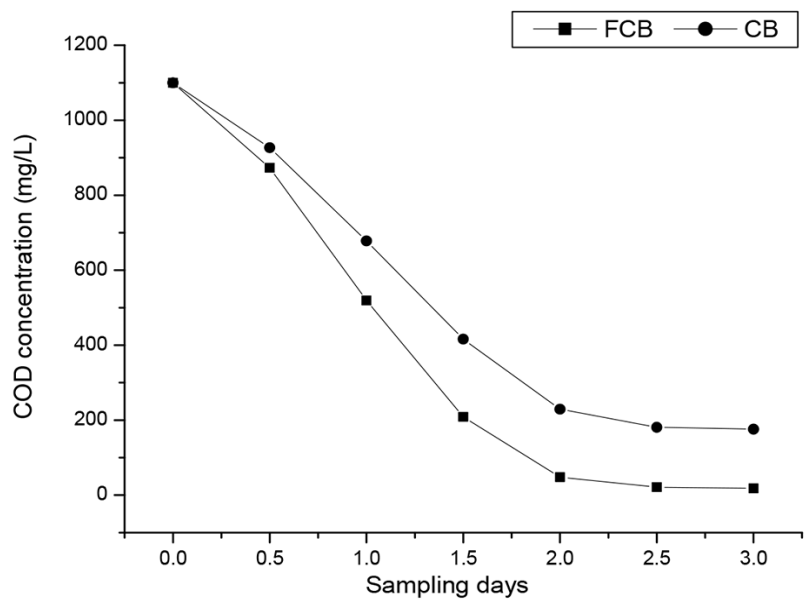

Fig. 1. COD removal in $\mathrm{FCB}$ and $\mathrm{CB}$.

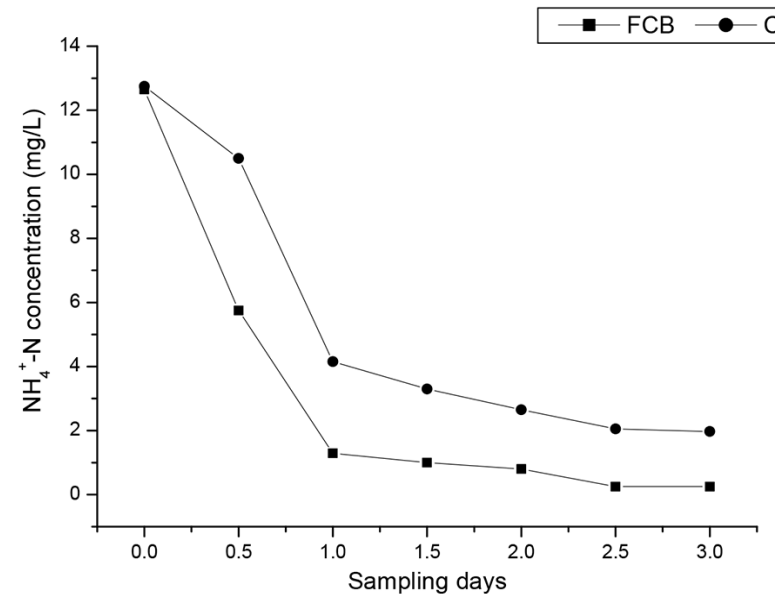

Fig. 2. $\mathrm{NH}_{4}{ }^{+}-\mathrm{N}$ removal in $\mathrm{FCB}$ and $\mathrm{CB}$.

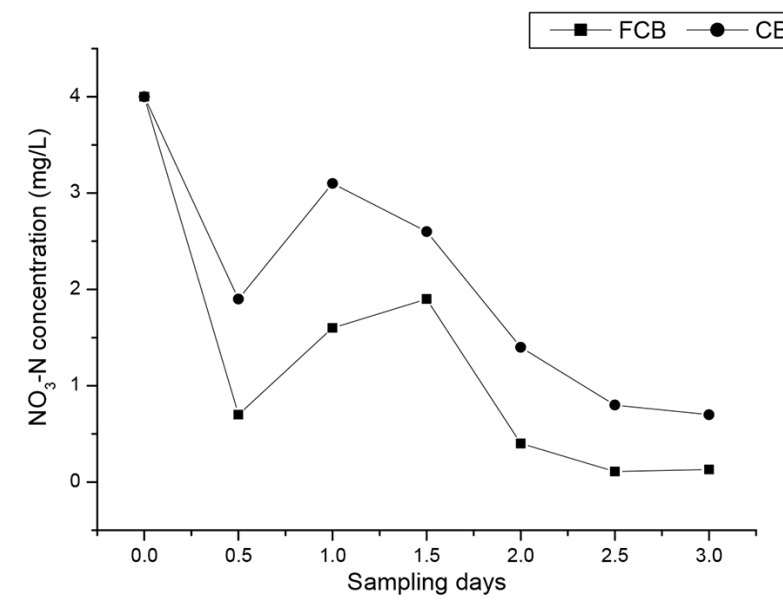

Fig 3. $\mathrm{NO}_{3}-\mathrm{N}$ concentration with time in $\mathrm{FCB}$ and $\mathrm{CB}$.

FCB, though complete $\mathrm{NO}_{3}-\mathrm{N}$ removal was achieved in both systems. $\mathrm{NO}_{3}-\mathrm{N}$ removal is desirable due to its role in eutrophication, methaemoglobinemia and cancers of the digestive tract [27, 28].

The higher reduction of produced water constitutents in FCB could be attributed to the spatial distribution of heterotrophic and autotrophic microorganisms on the biofilm [29]. Additionally, exogenous substrate consumption, re-stabilization of detached biofilms and nitrification was prominent in FCB [24]. The texture of the fine air bubbles in FCB was unique and represent a minor mechanism. Elemental analysis revealed the presence of functional groups such as alkyl halides, aromatics, carboxylics, amines and alcoholic compounds on the floating carrier material. These functional groups could facilitate biosorption of wastewater con-

Table 1. Summary of Reactor Performance

\begin{tabular}{|c|c|c|c|c|c|c|c|c|c|}
\hline \multirow[b]{2}{*}{ Days } & \multicolumn{3}{|c|}{ COD } & \multicolumn{3}{|c|}{$\mathrm{NH}_{4}{ }^{+}-\mathrm{N}$} & \multicolumn{3}{|c|}{$\mathrm{NO}_{3}-\mathrm{N}$} \\
\hline & $\begin{array}{c}\text { Influent } \\
\text { (mg/L) }\end{array}$ & $\begin{array}{c}\text { FCB } \\
(\%)\end{array}$ & $\begin{array}{l}\text { CB } \\
(\%)\end{array}$ & $\begin{array}{c}\text { Influent } \\
\text { (mg/L) }\end{array}$ & $\begin{array}{c}\text { FCB } \\
(\%)\end{array}$ & $\begin{array}{l}\text { CB } \\
(\%)\end{array}$ & $\begin{array}{c}\text { Influent } \\
\text { (mg/L) }\end{array}$ & $\begin{array}{l}\text { FCB } \\
(\%)\end{array}$ & $\begin{array}{l}\text { CB } \\
(\%)\end{array}$ \\
\hline 1 & 1,480 & 41 & 25.9 & 14 & 85.7 & 56 & 4 & 82.5 & 52.5 \\
\hline 2 & 1,480 & 85.9 & 71.9 & 14 & 92.8 & 76.5 & 4 & 52.5 & 22.5 \\
\hline 3 & 1,480 & 98.6 & 87.8 & 14 & 98.2 & 85 & 4 & 96.7 & 82.5 \\
\hline
\end{tabular}


stituents through the interaction of their functional groups with the reactive particles of produced water in FCB. The floating carrier materials provided the microorganisms sufficient surface area for growth and protection against toxicity and inhibition [30].

The shape, size and nature of carrier material can influence system performance. High organic matter degradation has been reported with several conventional biofilm carrier materials such as sponge [31], bio-balls [32], kaldness [33] and schists [34]. Khoshfetrat et al. [35] achieved a COD removal of about $90 \%$ using 1,372 pieces of polypropylene support materials in a submerged fixed-film bioreactor treating synthetic wastewater. Sarti et al. [18] achieved a COD removal in the range of $68-82 \%$ in a HAIB system treating low strength wastewater using polyurethane foam blocks as support materials. However, some floating carrier materials such as polyurethane foam are hydrophobic and have a net negative surface charge which repels the attraction of bacterial cells of similar charge and could cause a prolonged biofilm formation [36]. Additionally, carrier materials such as chitosan are sensitive to $\mathrm{pH}$ [37]. Chu et al. [36] compared the biofilm formation on a polyurethane foam (PUF) and a modified polyurethane foam (MPUF). The authors observed that biofilm formation was rapid and higher (1.3 times) on the MPUF compared to PUF due to the improved hydrophilicity of MPUF. Chen et al. [37] observed that chitosan was sensitive to $\mathrm{pH}$ due to its surface properties in their study of phenol degradation.

The use of non-conventional agricultural and solid waste carrier materials such as rice husk [38], fireclay [39], coir geotextiles [40] and fiber thread [41] have demonstrated effective treatment capability. These non-conventional carrier materials are hybrid (hydrophilic and hydrophobic) and degradable. The air flowrate required for carrier flotation is low compared to the conventional carriers and biofilm formation is rapid. Thus, the use of Gardenia Carinata shell as a floating carrier material is a promising technique to improve produced water biodegradation and solid waste management. The results obtained in this study for FCB is consistent with literature and largely depend on biofilm formation. The $\mathrm{pH}$ of both bioreactors was in the optimum range (6.9-7.8) for nitrification throughout the experiment.

\subsection{Kinetic Evaluation}

The bioreactors were evaluated on the basis of substrate removal rate using the expression in Eq. (1)

$$
-\frac{d S}{d t}=K_{s} X\left(\frac{S}{S_{o}}\right)^{n}
$$

Where $d s / d t$ is the substrate removal rate $(\mathrm{g} / \mathrm{L} / \mathrm{d}), K$ is the kinetic constant, $X$ is the biomass concentration $(\mathrm{mg} / \mathrm{L}), S_{o}$ and $S$ are the influent and effluent substrate concentration(mg COD/L).

The kinetic data were plotted using Origin 7.0 software. Origin 7.0

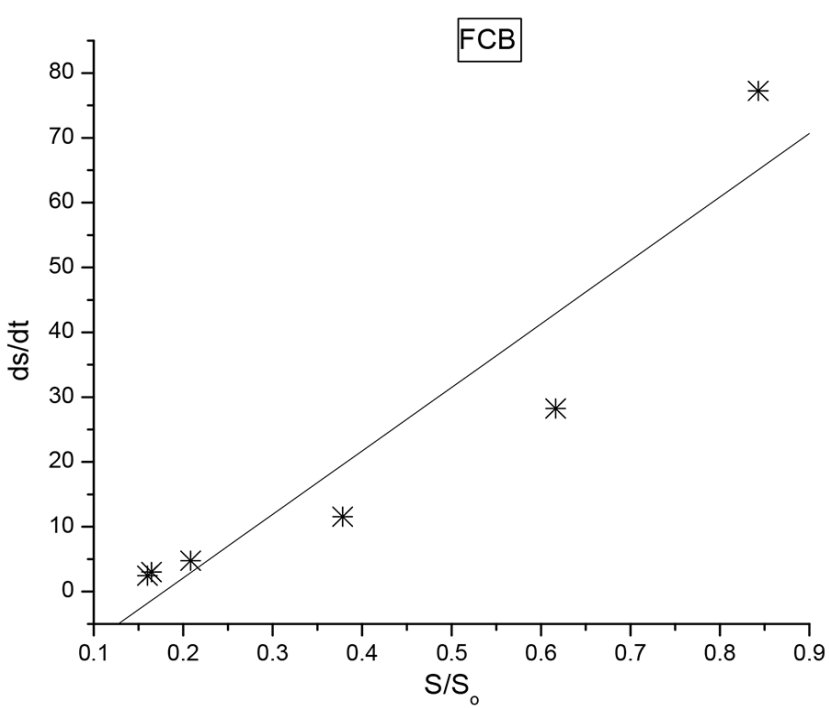

Fig. 4. Substrate removal rate for FCB.

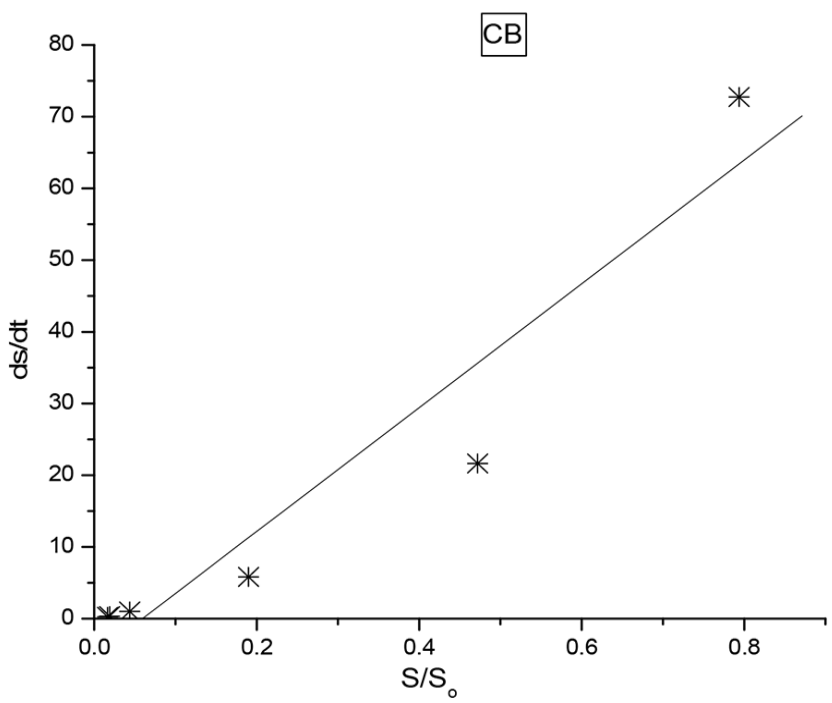

Fig. 5. Substrate removal rate for $\mathrm{CB}$.

software is a multipurpose, scientific and technical data analysis tool used to solve specific problems. It could be used to manage, create, explore and organize results and graphs. The kinetic data were fitted into a least square fit model in Origin 7.0 software and a linear regression was obtained at 95\% confidence level in Fig. 4 (FCB) and Fig. 5 (CB). The probability value (P), coefficient of determination $\left(\mathrm{R}^{2}\right)$, substrate removal rate $(\mathrm{k})$, standard deviation (Std. Dev) and standard errors (Std. Err.) were obtained and presented in Table 2. The probability values $(\mathrm{P})$ less than 0.05 indicate a significant model term. The P-values for both FCB and CB were

Table 2. Kinetic Constants for FCB and $\mathrm{CB}$

\begin{tabular}{cccccc}
\hline Bioreactor & $\mathbf{R}^{\mathbf{2}}$ & $\mathbf{k}(\mathbf{L} / \mathbf{d})$ & $\mathbf{9 5} \%$ Confidence level & Std. Dev. & Std. Err \\
\hline FCB & 0.943 & 97.93 & 0.0047 & 1.08 & 1.3 \\
CB & 0.956 & 86.36 & 0.0028 & 1.811 & 1.1 \\
\hline
\end{tabular}


low and significant (Table 1). The P-values for FCB and CB indicate a low probability of random error in the sample population. The coefficient of determination $\left(\mathrm{R}^{2}\right)$ for FCB and CB were high (> $0.9)$ in Table 2. The substrate removal rate for FCB $(97.93 \mathrm{~L} / \mathrm{d})$ were higher compared to $\mathrm{CB}(86.36 \mathrm{~L} / \mathrm{d})$. The standard deviation and standard error were low for FCB and CB.

\section{Conclusions}

The performance of an activated sludge system assisted with a floating carrier material made from an abundant agricultural solid waste material (Gardenia carinata shell) was investigated in a batch study for the treatment of produced water. The results clearly indicate that the carrier materials caused the rapid decrease of produced water constituents compared to the suspended control bioreactor. COD, $\mathrm{NH}_{4}{ }^{+}-\mathrm{N}$ and $\mathrm{NO}_{3}-\mathrm{N}$ removal were $99 \%, 98 \%$ and $98 \%$ for the FCB and $88 \%, 84 \%$ and $83 \%$ for the suspended control bioreactor, respectively. The mechanism for substrate removal in both bioreactor were identified as substrate consumption and nitrification. However, in the FCB, the texture of the rising air bubbles suggests the presence of another mechanism (biosorption). The following conclusions can be drawn from this study:

(a) The addition of suitable floating carrier materials in activated sludge enhances the overall performance of the bioreactor.

(b) Biofilm formation is rapid due to the stable and degradability potential of natural carrier materials.

(c) After biofilm formation on the floating carrier materials, rapid reduction of wastewater constituents is triggered by the spatial substrate competition between different kinds of microorganisms on the biofilm.

(d) The floating carrier material provides adequate surface area for the attachment of bacteria and reduces both substrate inhibition and potential toxicity.

(e) The use of solid waste materials with surface functional groups as floating carrier materials is highly beneficial due to the contribution of their inherent properties into the activated sludge system which further enhances the process.

\section{Acknowledgments}

This study was supported by Universiti Teknologi PETRONAS (UTP). The authors are therefore grateful to UTP.

\section{References}

1. Valipour M, Singh VP. Global experiences on wastewater irrigation: Challenges and prospects. In: Maheshwari B, Singh VP, Thoradeniya B, eds. Balanced urban development: Options and strategies for liveable cities. New York: Springer; 2016. p. 289-327.

2. Valipour M. Necessity of irrigated and rainfed agriculture in the world. Irrig. Drain. Sys. Eng. 2013;2:S9-e001.

3. Yannopoulos SI, Lyberatos G, Theodossiou N, et al. Evolution of water lifting devices (pumps) over the centuries worldwide. Water 2015;7:5031-5060.
4. Valipour M. Evolution of irrigation-equipped areas as share of cultivated areas. Irrig. Drain. Sys. Eng. 2013;2:e114.

5. Ezechi EH, Isa MH, Kutty SRM. Removal of boron from produced water by electrocoagulation. In: 10th WSEAS International Conference on Environment, Ecosystems and Development; 29-31 December 2012; Switzerland. p. 87-92.

6. Fakhru'l-Razi A, Pendashteh A, Abdullah LC, Biak DRA, Madaeni SS, Abidin ZZ. Review of technologies for oil and gas produced water treatment. J. Hazard. Mater. 2009;170: 530-551.

7. Woodall DW, Gambrell RP, Rabalais NN, DeLaune RD. Developing a method to track oil and gas produced water discharges in estuarine systems using salinity as a conservative tracer. Mar. Pollut. Bull. 2001;42:1118-1127.

8. Lu M, Zhang Z, Yu W, Zhu W. Biological treatment of oilfield-produced water: A field pilot study. Int. Biodeter. Biodegr. 2009;63:316-321.

9. Veil JA, Puder MG, Elcock D, Redweik Jr RJ. A white paper describing produced water from production of crude oil, natural gas, and coal bed methane [Internet]. Argonne National Laboratory for the US Department of Energy, National Energy Technology Laboratory; c2004 [cited January 2004]. Available from: http://www.ead.anl.gov/pub/dsp_detail.cfm.

10. Ezechi EH, Isa MH, Kutty SRM. Boron in produced water: Challenges and improvements: A comprehensive review. J. Appl. Sci. 2012;12:402-415.

11. Glickman A. Produced water toxicity: Steps you can take to ensure permit compliance. In: API Produced Water Management Technical Forum and Exhibition; 17-18 November 1998; Lafayette, Louisiana.

12. Cline J. Treatment and discharge of produced water for deep offshore disposal. In: API Produced Water Management Technical Forum and Exhibition; 17-18 November 1998; Lafayette, Louisiana.

13. Dallbauman L, Sirivedhin T. Reclamation of produced water for beneficial use. Separ. Sci. Technol. 2005;40:185-200.

14. Ezechi EH, Isa MH, Kutty SRM, Yaqub A. Boron removal from produced water using electrocoagulation. Process Saf. Environ. 2014;92:509-514.

15. Ciarapica F, Giacchetta G. The treatment of produced water in offshore rig: Comparison between traditional installations and innovative systems. In: 5th International Membrane Science \& Technology Conference; November 2003; Univ. of New South Wales, Sydney, Australia.

16. Liu G, Ye Z, Tong K, Zhang Y. Biotreatment of heavy oil wastewater by combined upflow anaerobic sludge blanket and immobilized biological aerated filter in a pilot-scale test. Biochem. Eng. J. 2013;72:48-53.

17. Han M, Zhao Z, Gao W, Cui F. Study on the factors affecting simultaneous removal of ammonia and manganese by pilot-scale biological aerated filter (BAF) for drinking water pre-treatment. Bioresource Technol. 2013;145:17-24.

18. Sarti A, Vieira LGT, Foresti E, Zaiat M. Influence of the liquid-phase mass transfer on the performance of a packed-bed bioreactor for wastewater treatment. Bioresource Technol. 2001;78:231-238.

19. Ezechi EH, Isa MH, Kutty SR, Sapari NB. Boron recovery, 
application and economic significance: A review. In: National Postgraduate Conference (NPC), in IEEE: 19-20 September 2011; Malaysia. p. 815-820.

20. Eaton AD, APHA, AWWA, WEF. Standard methods for the examination of water and wastewater. 21st ed. Washington D.C.: APHA-AWWA-WEF; 2005.

21. Ezechi EH, Isa MH, Kutty SRM, Ahmed Z. Electrochemical removal of boron from produced water and recovery. J. Environ. Chem. Eng. 2015;3:1962-1973.

22. Isa MH, Ezechi EH, Ahmed Z, Magram SF, Kutty SRM. Boron removal by electrocoagulation and recovery. Water Res. 2014;51:113-123.

23. Hach. Water analysis handbook. 4th ed. Loveland: Hach; 2002. p. 61-62.

24. Hamoda M, Zeidan M, Al-Haddad A. Biological nitrification kinetics in a fixed-film reactor. Bioresource Technol. 1996;58:41-48.

25. Ramos A, Gomez M, Hontoria E, Gonzalez-Lopez J. Biological nitrogen and phenol removal from saline industrial wastewater by submerged fixed-film reactor. J. Hazard. Mater. 2007;142:175-183.

26. Wang Y, Huang X, Yuan Q. Nitrogen and carbon removals from food processing wastewater by an anoxic/aerobic membrane bioreactor. Process Biochem. 2005;40:1733-1739.

27. Camargo JA, Alonso A, Salamanca A. Nitrate toxicity to aquatic animals: A review with new data for freshwater invertebrates. Chemosphere 2005;58:1255-1267.

28. Ghafari S, Hasan M, Aroua MK. Bio-electrochemical removal of nitrate from water and wastewater-A review. Bioresource Technol. 2008;99:3965-3974.

29. Wijeyekoon S, Mino T, Satoh H, Matsuo T. Effects of substrate loading rate on biofilm structure. Water Res. 2004;38:2479-2488.

30. Tziotzios G, Teliou M, Kaltsouni V, Lyberatos G, Vayenas D. Biological phenol removal using suspended growth and packed bed reactors. Biochem. Eng. J. 2005;26:65-71.

31. Nguyen TT, Ngo HH, Guo W, Johnston A, Listowski A. Effects of sponge size and type on the performance of an up-flow sponge bioreactor in primary treated sewage effluent treatment. Bioresource Technol. 2010;101:1416-1420.

32. Masłoń A, Tomaszek JA. A study on the use of the BioBall ${ }^{\circledR}$ as a biofilm carrier in a sequencing batch reactor. Bioresource Technol. 2015;196:577-585.

33. Beristain-Cardoso R, Gómez J, Méndez-Pampín R. The behavior of nitrifying sludge in presence of sulfur compounds using a floating biofilm reactor. Bioresource Technol. 2010:101 8593-8598.

34. Hernandez AR, Susa MR, Andres Y, Dumont E. Steady- and transient-state $\mathrm{H}_{2} \mathrm{~S}$ biofiltration using expanded schist as packing material. New Biotechnol. 2013;30:210-218.

35. Khoshfetrat AB, Nikakhtari H, Sadeghifar M, Khatibi MS. Influence of organic loading and aeration rates on performance of a lab-scale upflow aerated submerged fixed-film bioreactor. Process Saf. Environ. 2011;89:193-197.

36. Chu L, Wang J, Quan F, Xing XH, Tang L, Zhang C. Modification of polyurethane foam carriers and application in a moving bed biofilm reactor. Process Biochem. 2014;49:1979-1982.

37. Chen YM, Lin TF, Huang C, Lin JC, Hsieh FM. Degradation of phenol and TCE using suspended and chitosan-bead immobilized Pseudomonas putida. J. Hazard. Mater. 2007;148:660-670.

38. Shao L, Xu Z, Jin W, Yin H. Rice husk as carbon source and biofilm carrier for water denitrification. Polish J. Environ. Stud. 2009;18:693-699.

39. Tilaki RAD. A study on using fireclay as a biomass carrier in an activated sludge system. J. Ind. Microb. Biotechnol. 2011;38:209-213.

40. Mukkulath G, Thampi SG. Performance of coir geotextiles as attached media in biofilters for nutrient removal. Int. J. Environ. Sci. 2012;3:784-794.

41. Jin Y, Ding D, Feng C, Tong S, Suemura T, Zhang F. Performance of sequencing batch biofilm reactors with different control systems in treating synthetic municipal wastewater. Bioresource Technol. 2012;104:12-18. 